\title{
Editorial
}

\section{Connecting History and Foresight for Unprecedented Innovation Journeys}

\author{
João José Pinto Ferreira ${ }^{1}$, Anne-Laure Mention ${ }^{2}$, Marko Torkkeli ${ }^{3}$ \\ ${ }^{1}$ INESC TEC - INESC Technology and Science and FEUP - Faculty of Engineering, University \\ of Porto, Portugal; ${ }^{2}$ RMIT University, Australia; ${ }^{3}$ Lappeenranta University of Technology, \\ Finland \\ anne-laure.mention@rmit.edu.au, jjpf@fe.up.pt, \\ marko.torkkeli@lut.fi
}

"What all the successful entrepreneurs I have met have in common is not a certain kind of personality but a commitment to the systematic practice of innovation."

"Innovation is the specific function of entrepreneurship, whether in an existing business, a public service institution, at a new venture started by a lone individual in the family kitchen."

\section{Peter Drucker}

It is common knowledge that history repeats itself! Maybe not literally, but patterns of behaviour likely dependent of the human nature, are probably prone to repeat themselves. So, one may wonder if looking back could help us prepare for a better future. Moreover, by looking back at the history of people and societies, we should all be able to have a better understanding of why things happen the way they do. This seldom happens, and when it does, it is happening within very limited circle of the society such as scholars and some politician circles, rarely overflowing to the whole society.

The point is that, what we see today is not very different from what has happened in the past. Let us go back to November 13, 1460, the day Prince Henry the Navigator, passed away in Sagres, leaving Portugal with an enormous debt. Despite that fact, Prince Henry was the "guiding force behind Portugal's assimilation of nautical knowledge and its vast extension of maritime exploration for nearly four decades" (Kock, 2003, p.59). It is interesting that by that time intellectual property was already being managed. After Prince Henry's death King Afonso V, “decreed that all discoveries derived from these explorations were the physical of intellectual property rights of Portugal alone, and henceforth to remain well-guarded and state secret" (Ibid., p.62). Along these endeavors, many innovations emerged, probably not known as "innovations", at the time. For example, the North Start was used to calculate the latitude in the northern hemisphere, however, as ships approached and crossed equator this star was no longer visible and they had to figure out a solution to determine their exact position in the southern hemisphere. To that end they devised "tables of declination based on the position of the sun as well as the formation of stars 
known as Southern Cross" (Ibid., p.62). This was just the beginning, but to make the long story short, Portugal was finally the first to reach the lands of the Indies by way of the sea! (Ibid., p.2).

The Portuguese discoveries reveal plenty of examples of much of what we today relate to entrepreneurship and innovation. In fact, the entrepreneur was there with a dream, and was able to engage everyone around him/her in the pursuance of that dream. There were also the investors, and those who did not believe it, as his own brother, "during his lifetime he [Prince Henry] often found himself the object of ridicule" (Ibid., p.59)!

As put by António Gedeão (Portuguese poet - lived from 1906 to 1997) in his poem "Pedra Filosofal" (Philosopher's stone):$$
\text { “( (..) }
$$$$
\text { Eles não sabem, nem sonham, }
$$$$
\text { que o sonho comanda a vida. }
$$$$
\text { Que sempre que o homem sonha }
$$$$
\text { o mundo pula e avança }
$$$$
\text { como bola colorida }
$$$$
\text { entre as mãos de uma criança." }
$$

“(...)

They neither know, nor dream,

that dreams command life.

That whenever a man dreams

the world bounces and advances,

like a coloured ball

in the hands of a child."

This is indeed not new, the power of dreams and the need for visionaries. It is, as well, a most interesting demonstration that innovation is not a one man/woman show and that innovation is spurred through collaboration!

Fast forward to the current days, and the perception of time is different. Each clock tic takes exactly the same time, but it somehow it seems faster, but why? We could have many explanations, the world economics would likely explain most of it, but people drive economics, at least they should, so, the question is what could we learn from the past? What could these teachings on innovation and entrepreneurship, not only from the Portuguese Discoveries but also from many other relevant and interesting experiences around the world, bring to today's entrepreneurs and innovators? We would like to challenge a combined effort of historians and innovators to seek cooperation and lend each other a helping hand!

"Historians have applied their method to a wider variety of subjects; regardless of the topic, historians ask questions, seek evidence, draw inferences from that evidence, create representations, and subject these representations to the scrutiny of other historians." (Staley, 2010, p.1). This is not so different from approaches used by other researchers, such as the ones working on the so-called Foresight. Foresight has been established as a tool to generate scenarios beyond the "reasonable"/expectable and foreseeable horizon, as an instrument for horizon scanning, as a structured approach to support decision making, and policy making. It self-embeds the notion of exploration, allowing unleashing opportunities, acting as a catalyst for mind opening activities. In itself, its application to design, sketch and define innovation strategies is 
self-explanatory and undeniably rewarding. Yet, as of today, it is seldom used by innovators and we also call for futures and foresight experts to lend a helping hand to innovators!

We wish an enjoyable journey for historians, innovators and foresight researchers, working hands in hands in sketching and implementing enjoyable innovation journeys, leading to unprecedented discoveries!!

Innovatively Yours,

Anne-Laure Mention, João José Pinto Ferreira, Marko Torkkeli

Editors

\section{References}

Drucker, P. F. (1999). The Discipline of Innovation. Harvard Business Review on Breakthrough Thinking. p. 142-160. ISBN 1-57851-181-X

Koch, Peter O. (2003). Following the Dream of Prince Henry. To the Ends of the Earth: The Age of the European Explorers. McFarland \& Company. p. 62. ISBN 0-7864-1565-7.

Staley, D. J. (2010). History and Future: Using Historical Thinking to Imagine the Future, Lexington Books. ISBN-13: 978-0739117538. ISBN-10: 073911753X 